Article

\title{
Who Belongs, and How Far? Refugees and Bureaucrats Within the German Active Welfare State
}

\author{
Katrin Menke * and Andrea Rumpel \\ Institute for Work, Skills and Training, University Duisburg-Essen, Germany \\ * Corresponding author (katrin.menke@uni-due.de)
}

Submitted: 30 June 2021 | Accepted: 9 December 2021 | Published: 22 March 2022

\begin{abstract}
Concepts such as "belonging" (Yuval-Davis, 2011) and "community of value" (Anderson, 2013) try to capture the multiple ways of classifying migrants. In this article, we argue that belonging needs to be analyzed against the backdrop of active social citizenship in European welfare states. Although the literature acknowledges the increasing links between migration and social policies, the latest "turn to activation" in social policy has hardly been accounted for. By focusing on two policy fields in Germany, the labor market and health policies, we briefly describe discourses and social right entitlements and their ambivalences. Empirically we show (a) how bureaucrats within the two policy fields regulate and justify refugees' social rights in practice and (b) how refugees act vis-à-vis relevant institutional opportunity structures. Our study contributes to previous research twofold: Firstly, we illustrate processes of positioning and selecting refugees that stem from recent social policy architecture. Secondly, we demonstrate everyday experiences from refugees' vis-á-vis relevant institutional opportunity structures in Germany. Our results show that inconsistencies within and between social policy fields of one welfare state have to be taken into consideration for further national and transnational research.
\end{abstract}

\section{Keywords}

active social citizenship; belonging; health policy; labor market policy; migration policy; female refugees; social policy; welfare states

\section{Issue}

This article is part of the issue "Transnational Social Protection: Inclusion for Whom? Theoretical Reflections and Migrant Experiences" edited by Elisabeth Scheibelhofer (University of Vienna), Emma Carmel (University of Bath), and Anna Amelina (University of Cottbus).

(C) 2022 by the author(s); licensee Cogitatio (Lisbon, Portugal). This article is licensed under a Creative Commons Attribution 4.0 International License (CC BY).

\section{Introduction}

Consistent with a demigrantization of migration research, an emerging strand in migration studies focuses on how migrants are societally "produced" (Mezzadra \& Neilson, 2012; Morris, 2020). Concepts such as "belonging" (Yuval-Davis, 2011) and "community of value" (Anderson, 2013) try to capture the complex and dynamic ways of "producing" and classifying migrants. In this article, we discuss belonging against the backdrop of recent social policies. Although the interplay of social and migration policies is examined (Ataç \& Rosenberger, 2019; Hollifield, 2000), the context of an "active social citizen" within contemporary European welfare states
(Eggers et al., 2019, p. 43) has not yet received much attention. We argue that the linkage between migration, welfare, and belonging cannot be fully captured without considering political paradigms such as activation and self-responsibility due to their meaning as societal discourses and restructuring character of social rights. By analyzing the interplay of asylum policy with two social policy fields in Germany, we illustrate how health policies and labor market policies produce a picture of "who belong[s], how far they belong and under which conditions" (Carmel \& Sojka, 2020, p. 2). Our empirical findings illustrate (a) how bureaucrats regulate and justify refugees' social rights in practice and (b) how refugees act vis-à-vis relevant institutional opportunity 
structures. We use qualitative interviews with bureaucrats in welfare institutions and refugees to investigate these relationships. Our study makes two contributions to previous research: Firstly, we examine the question of which refugees belong, how much they belong, under which conditions, and how this is related to recent social policy paradigms. Secondly, we adopt a multidimensional definition of belonging and put it into the context of active social citizenship to empirically shed light on refugees' individual experiences, an under-explored side of the concepts of belonging (Amelina et al., 2020, pp. 9-10, 207). With our empirical examples of female and substance-using refugees, we disclose interconnections between different levels of migration and integration policies as well as the activation paradigm and demonstrate refugees' everyday experiences.

In the following section, we explain the theoretical conception of belonging and how it influences the everyday in- and exclusion of migrants. Secondly, we describe the recent context of active social citizenship and illustrate this within Germany's labor market and health policies. The subsequent section presents our empirical findings and illustrates how bureaucrats put rationales of belonging into practice and how refugees react to them. In the following discussion, we draw links from different concepts of belonging and assess how refugees act within their given conditions in the health and labor sectors with different ways of handling. The article ends with a conclusion, which shows the importance of bureaucrats in welfare institutions and how they influence the ways of handling.

\section{Belonging as a New Dimension of Everyday Inclusion and Exclusion}

Migration research has for some time considered inand exclusion as a dichotomous social process. Due to a changed understanding of stratification processes as complex, multi-layered, and dynamic (Mezzadra \& Neilson, 2012), concepts of belonging have become more important (Anderson, 2013; Yuval-Davis, 2011). They capture parallel forms of daily experiences of in- and exclusion by considering three different dimensions of belonging: Firstly, a person's emotional attachment and individual identification (Yuval-Davis, 2011). Constructions of belonging can be seen as a performative act of the individual by repetitive practices and struggle or resistance, or both (Yuval-Davis, 2011, p. 25). Secondly, formal and informal access to social rights is related to one's own status position nationally (Morris, 2020) and transnationally (Amelina et al., 2020). Thirdly, concepts of belonging enable the analysis of societal discourses that construct belonging to (national) collectives in a normative way. Anderson (2013, pp. 2-5) underlines that these "communities of values' remain in the imaginary realm. The interplay of dimensions 2 and 3 is what Carmel and Sojka (2020, p. 2) refer to as differential "rationales of belonging." According to them, this range of discursive reasoning around status, rights, and membership provides organizational logics and practices that are, in fact, racialized, classed, and gendered (Carmel \& Sojka, 2020, p. 4). Taken together, these dimensions decide "who belongs, how far they belong and under which conditions" (Carmel \& Sojka, 2020, p. 2). Anderson (2013, pp. 3-7) describes the legally and normatively constructed citizen as being placed on a continuum between "good," "tolerated," "and "failed"-a categorization that we will refer to later on. Overall, new hierarchies are arising among migrants as well as between migrant and non-migrant citizens.

We adopt this multidimensional definition of belonging, but we expand the analysis in two important ways: We consider processes of in- and exclusion that evolve from a context in which active social citizenship becomes crucial beyond migration processes. Furthermore, we empirically shed some light on the refugees' strategies. Although migrants' individual experiences build the main part of the concepts of belonging (Amelina et al., 2020, pp. 9-10, 207), empirical research on this is rare.

\section{The Community of Value Within the Transformed German Welfare State}

Literature on the interplay of social and migration policies stresses the argument that social policy regulates migrants' access to social rights in order to control and limit their mobility into, out of, and within nation-states (Ataç \& Rosenberger, 2019; Hollifield, 2000). While migration policies are described as facilitating mechanisms of territorial and social in- and exclusion, social policies are commonly perceived as aiming to achieve equality, facilitate social participation, and improve well-being for (national) citizens (Ataç \& Rosenberger, 2019, p. 3). In this nexus, insight from recent social policy analysis regarding European welfare states' paradigms such as activation, self-responsibility, and social investment (Bonoli \& Natali, 2012) are not commonly considered. However, the principle of active social citizenship (Eggers et al., 2019) frames societal discourses and social institutions. The states' responsibility for social security differs between and within welfare states, which is accompanied by new challenges for citizens to secure their livelihood and well-being (Eggers et al., 2019). Effects discussed in the literature range from supporting the citizens' agency (in the sense of self-determination) to imposing obligations and requiring that they take on risk (greater self-responsibility). However, active social policies address citizens and refugees equally but have different effects. These are rarely explored (Hagelund \& Kavli, 2009). We argue that active social citizenship establishes specific norms of belonging and produces differential forms of inclusion for refugees, who are confronted with additional challenges. In the following section, we give evidence of how active social citizenship applies to two different policy fields in Germany. 


\subsection{Labor Market Policies Towards Activation}

Labor market participation has become a yardstick for measuring social integration. Discursively, being unemployed is labeled not only as a risk to one's own social security but also as a problem for the (national) social insurance community. The active labor market programs correlate with pressure on job seekers to enter low-wage and non-standard forms of work. Two forms of unemployment benefit exist: unemployment insurance for up to one year (ALG I) and a flat-rate, means-tested benefit (ALG II; Greer \& Symon, 2014, p. 12). The literature describes this regime as inconsistent because recipients of ALG I are supported by a major role of the state, while those that receive ALG II are forced to be self-responsible based on relatively low benefits and strict eligibility conditions (Eggers et al., 2019, pp. 52-53). Refugees with a residence permit are always confronted with the stricter paradigm within the ALG II system. Additionally, social active citizenship interplays with family and gender equality policies inconsistently: Some instruments incentivize a (mostly male) family wage (e.g., German co-insurance regulations for the non-contributory spouse in the health and care insurance system, mini-jobs). However, within the ALG II system, all adults within one household have to be available for (all kinds of) full-time work regardless of their care duties (even if they have children under three years of age). Since women still perform the majority of unpaid care work, they are primarily responsible for managing divergent demands (Auth et al., 2010; Betzelt, 2015).

Activation policies and discourses, likewise, apply to newly arrived refugees (Salikutluk \& Menke, 2021, pp. 3-4). Refugees' overall access to the labor market has been eased considerably in the last decade but still depends on residential status and type of protection awarded (for an overview see Schwenken, 2021, pp. 141-142). While early screenings and access to labor market integration measures create opportunities for easier and faster access to the labor market, differential inclusion of heterogeneous refugee groups emerges (Schwenken, 2021, p. 135).

However, female refugees face additional challenges to comply with the need for active social citizenship. The reconciliation of paid and unpaid work is exacerbated due to the absence of support from further relatives or missing access to childcare facilities that accept dualearner couples first. Furthermore, societal discourses on female employment affect approaches to refugees' labor market integration (Ghorashi \& van Tilburg, 2006; Koyama, 2015). Moreover, research on migrants receiving ALG II revealed cultural ascriptions, particularly against female Muslims within labor market organizations (Jaehrling \& Knuth, 2010). From the bureaucrats' perspective in the public employment service, a lack of language skills, qualifications that do not apply to the labor market, being unaware of German gender roles, and having domestic care duties are the most commonly stated reasons for barriers that refugees (mostly female) usually face when entering the labor market (Dietz et al., 2018). This makes it more difficult for them to be recognized as potential employees.

\subsection{Health Policies Towards Self-Responsibility}

There are three main rationales in health care, which were used as a validation for altering the welfare state: (a) the meaning of knowledge-based services, (b) the economization of health care with cost-containment and the efficiency of public healthcare services, and (c) the marketization (privatization) of healthcare along with the expansion and commercialization of healthcare services and products (Ewert \& Evers, 2014). These alterations affect health care consumers in different ways. Knowledge-based services ask for more selfresponsibility on the part of each individual and have become one of the main pillars of health care policy. Consumers act as co-producers and are expected to contribute to their own health as active social citizens; this is why Ewert and Evers (2014) employ the term "users." Users should be able to research and classify information in order to draw individual conclusions. Due to a lack of prior knowledge about the German health care system and its medical options, this has a selective effect on refugees. Economic policy rationales, which can be observed as a part of economization, lead to an evaluation of costs and benefits and transform patients into active consumers. They lead to patient-based selectivity, who now receive either support or face restrictions due to personal resources such as self-responsibility and economic considerations (Ewert \& Evers, 2014; Rothgang et al., 2005). This context also affects refugees, who are being asked by health policy to be equally self-responsible and economically minded, while having fewer resources to accomplish this. Additionally, health is a social product; it differs between societies, groups, and generations (Conrad \& Barker, 2010; Flick, 2000). These discourses manifest themselves through social constructions in the health system. Refugees are confronted with an ambitious health policy and have to take care of their own health concerns.

Health treatment for refugees is structurally differenced into two possible options: (a) refugees with a recognized asylum status who are in the statutory health insurance and (b) "tolerated" refugees and refugees in the first 18 months of the asylum process who are covered by the Asylum Seekers Benefits Act, which limits access to the health care system by only providing acute treatment.

\section{Methodology}

Our empirical findings result from qualitative fieldwork in Germany coming from two separate projects within a shared research group. The first project explores the labor market participation of female refugees from an 
intersectional perspective. The analysis is based on narrative biographical talks with female refugees and semistructured expert interviews with local labor market experts (bureaucrats from job centers, providers of labor market measures, city administration, and welfare organizations) in two municipalities. While access to the labor market experts derived from official requests, access to the female refugees was based on personal introductions at regular meeting times at the counseling points of welfare organizations and in labor market measures. The sample consists of interviews with 20 local labor market experts and 16 female refugees, 12 of whom identified themselves as being Muslim. The second research project explores refugees' inclusion and exclusion throughout local health policies by using the example of substance-using refugees. Twelve narrative biographical talks with ten substance-using refugees in three heterogeneously selected municipalities were conducted. Access to the field varied and was realized through shelters, addiction services, social workers, or medical staff. The conversations varied between 45 minutes and three hours and were combined with other methods such as ethnographic and informal talks. The talks with refugees were conducted in a conversation triad with interpreters (Rumpel \& Tempes, 2019) or in pairs in English or German. Four expert interviews were conducted with staff from the social welfare office and municipal addiction coordination in the three municipalities. By keeping the legal regulation open, municipalities themselves can strongly influence the approach to health care for refugees through their regulations. The implementation takes place via the social welfare offices, and the bureaucrats there influence the implementation of municipal regulations. Therefore, the management of the responsible departments of the social welfare offices was included in the sample. Additionally, one addiction coordinator, which is not provided for in every municipality, was included in the sample in one municipality.

The methodological background of both projects is the iterative grounded theory (Strauss \& Corbin, 1994). The refugees' biographical talks were analyzed openly with the grounded theory methods' coding paradigm, focusing on conditions, interactions, and strategies from the refugees' perspective on using or not-using relevant welfare services in Germany. We focused especially on those parts in each interview that contained statements on contact with welfare state authorities. The expert interviews were evaluated by content analysis with inductive and deductive characteristics (Kuckartz, 2016) to adapt our research interest on formal and informal access to social rights. Deductive codes included the "cooperation in between authorities," "connections between asylum status and health care services or labor market integration, " or "local characteristics." Further inductive codes included, e.g., the "meaning of religion" (first project), the "handling of substance-use" (second project), or "bureaucratic assignment of obligation" (both projects). The qualitative material was repeatedly analyzed within an interpretation group, which helped identify the comparability of our data sets: Female refugees, especially those marked as Muslims, as well as substance-using refugees, are socially positioned at the periphery of citizenship. Both groups are confronted profoundly with societal discourses that raise questions of institutional access to social rights.

All interviews were conducted from 2018 to 2021; all quotes are provided with anonymous names.

\section{Producing Partial Belonging of Refugees in Germany}

The following section presents our empirical findings and illustrates first how bureaucrats put rationales of belonging into practice, and second, how refugees react to it. We start with the bureaucrats' perspective and female refugees' strategies in the field of labor market policies, followed by the field of health care policies.

\subsection{Rationales of Belonging in Labor Market Policies}

\subsubsection{The Bureaucrats' Perspective on Belonging}

Bureaucrats in the public employment service address female refugees primarily as accompanying spouses and mothers, not as autonomous subjects and potential employees. While childless or single women are perceived as an exception and are associated with higher education, women with caring responsibilities are described as being outside the labor market, less educated, and less willing. Some bureaucrats assume females adopt a child-bearing strategy to avoid being targeted by the authorities' activation practices. Most of the bureaucrats, though, link female refugees' perceived absence from the labor market to their specific cultural and Muslim religious ties:

There are clients who don't want to do anything. Because of their culture....When someone has been at home for 40 years, or has taken care of children for 30 years and so on, and has seven, eight children....You can't do anything with them.... The second group really wants to do something but isn't allowed to do so....The husband comes and says, "well, what can I do to keep my wife at home?" (Mister Deeb, pos. 420)

According to Mister Deeb, the first group of female refugees is neither willing nor qualified for the German labor market; the second group is described as willing to do paid work but hindered by their (heterosexual) gender relations. The women's seemingly low education level is traced back to the local gender relations within their countries of origin. Bureaucrats compared them with Germany's social status of women several decades ago:

If I look back to the Federal Republic in the sixties, seventies, it was different by then, too, wasn't it?...These 
structures are still alive in the five Big Players [main countries of origin]. (Mister Körber, pos. 1044)

According to this, female refugees first have to catch up with the recent societal position of women within the German majority society. However, bureaucrats who evaluate the women's language capabilities as particularly bad prescribe language qualifications, not with potential labor market participation in mind, but to enable them to communicate in German well enough to carry out domestic and care work, e.g., buying groceries, accompanying children to school or kindergarten, and making oneself understood to get medical treatments. By doing so, the bureaucrats express ethnographiccultural stereotypes and gendered assumptions around work and welfare that hinder female refugees from participating in the German labor market.

The differentiation between female refugees also becomes relevant for the bureaucrats' activation practices. Activation efforts remain restricted only to a few female refugees, as Miss Zimmer explains: "We pick out those women early already during parental leave, the ones we think want to achieve more, and hold talks and try to reveal pathways and motivate them" (Miss Zimmer, pos. 385). With this selection, many female refugees are not considered for personal education and training programs because bureaucrats assume them to be not (sufficiently) interested in participating in paid work. This contradicts the activation paradigm of the German welfare state.

The majority of female refugee mothers in the sample are not initially forwarded into language courses or labor market integration measures. If these women are on parental leave or their children are under three, the bureaucrats' activation practice varies. While some express dissatisfaction with their activation efforts being interrupted due to care work, others underline the lawful right of mothers to not be targeted by activation policies, irrespective of their legal status: "The rules are clear, women during parental leave are not obliged to cooperate with us during the first three years" (Miss Günes, pos. 460). However, Miss Günes offers optional consultation services for mothers on maternity leave, something she does voluntarily. Meanwhile, the majority of the bureaucrats concentrate on the women's husbands in order to realize a male family earner status: "Well, then [as a man] you should strive to earn enough for your family. That is your free choice" (Miss Deise, pos. 760). If one person earns enough, other household members of employable age usually become deregistered as job seekers and excluded from the authorities' job search services. Therefore, several women in the sample ended up living in a more traditional gender relation in Germany than they did in their country of origin.

Female refugees perceived as "sufficiently" educated and ambitious for the German labor market are moved into jobs that hardly match their educational level. Instead of recognizing diplomas, university degrees, and vocational or further qualifications, the bureaucrats expect the women to lower their sights. They are advised to pursue a strategy of smaller steps because such women "fall flat on their back quickly and afterward it takes a long time to do the construction work. That is why we show possible opportunities...to prevent them from experiencing too many failures" (Miss Zimmer, pos. 404). Those jobs that are offered to female refugees are mainly located in the low-wage sector within specific ethnicgendered fields, such as cleaning jobs.

\subsubsection{Female Refugees' Strategies}

Most of the interviewed women expressed discontent with the labor market authorities. A lot of women attest to a bad consultation service due to a lack of interest in their individual vocational plans. Especially those who wear headscarves feel that they are stereotyped by the bureaucrats: "We realized that the job center offers cleaning jobs especially to the women. But we are from a country in which we have studied, we educated ourselves" (Amina, pos. 152). Others feel pressured by the authorities' activation strategies. For instance, as Silda had been asked to use childcare facilities to get into the labor market, she ended up deregistering herself as a jobseeker: "They send me a letter pleading with me to send my children to the kindergarten so that I could start working or participate in a language course. After that, we resigned from the job center" (Silda, pos. 589). While her husband's income enables Silda to withdraw from the authorities, others do not have this option. Amina's husband only works part-time, which makes complementary social benefits necessary. A third group laments that they do not have any access to the job search services and mediation towards language courses and labor market measures. These women are mainly mothers of children under three, who do not have to be activated by the Job center. Ghusum, for example, actually wishes to start a German language course: "Not until today, because my daughter isn't three years old" (Ghusum, pos. 297).

The women are confronted with the authorities' selective addressing and develop two varying strategies. Some tend to seclude themselves from German authorities and thereby put off their own vocational plans into the future. Silda, who studied IT in Syria, would like to use her capabilities in the future: "I would like to learn the language to go ahead. Maybe I will study. I do have the capabilities; I would like to make use of them. Right now, my capabilities are restricted due to childcare obligations" (Silda, pos. 894). Meanwhile, she works in a warehouse, a job her husband mediated for her with his employer. Sara (pos. 294), a mother of five children, wants to get a place in the kindergarten for her two youngest children in order to learn German and start work "step by step." She has also postponed the recognition of her diplomas and several pieces of work experience).

Other women in the sample show resistance before the labor market authorities' practices and how they 
address them. These women articulate their dissatisfaction. However, critical intervention has had hardly any effect on the women's grievances. Although Naome, a teacher from Syria, made clear that she does not want to apply for cleaning jobs, her labor market consultant keeps sending her such jobs - to which she has to respond so as not to violate her obligation to cooperate. In the case of Naome, compliance with the approach, although not agreeing with it, turns out to be a tactical form of resistance since Naome is aware of her less powerful position vis-á-vis the authority. Others, like Amina, were sanctioned. Because she refused to apply for cleaning jobs and insisted on starting vocational training as a confectioner, the job center canceled the financing of her second language course. Since then, Amina has paid for a separate language course on her own:

I wanted to do vocational training; they said it was too difficult for me: "three years, you have children." I told them, "no, I want to do that." She said there were several other jobs where I could start working right away....After they realized that I kept holding on to my idea...they sent me appointments every two weeks and asked what I was doing. Although my exam was only in May. (Amina, pos. 808)

Allies within the system appear to be supportive of these women, such as welfare organizations, occasionally volunteers, or individuals with gatekeeper functions. For instance, women report better job agreements and a friendlier conversational tone with the labor market consultants when accompanied by volunteers from the wider society. Sometimes gatekeepers within the system, e.g., employees of external labor market measures, do see more potential in a woman than the labor market authority itself, as Aram experienced it:

When he heard me speaking German and saw that the labor market consultant wrote down "cleaning job," he couldn't believe it.... He said we [were] not going to do that, "we will find training in office management or something that would suit you far better." And he wrote a lot of mails to my labor market consultant in order to convince her. (Aram, pos. 497)

Aram, who worked as a lawyer in Syria, finally trained as a language mediator.

\subsection{Rationales of Belonging in Health Policies}

\subsubsection{Bureaucrats' Perspectives on Belonging}

The bureaucrats of the social security office constitute a difference between "the Germans" and "the refugees." This is based on the distinction accorded to nationality and by homogenizing countries of origin, e.g., Mister Keller (pos. 31): "The Gambia, Togo, Nigeria, in other words, the Central African states. They expect a better future here." Regarding substance use, further normative differences are marked: while Germans "get drunk peacefully" (Miss Beck, pos. 78) and "rather individually, not in such large groups" (Miss Beck, pos. 57), by way of this "logic," partying in groups transforms the (male) refugee into a criminal, ready to fight at the drop of a hat:

The refugees, there was one word or another, and the knife was drawn very quickly. And that was not the case with the Germans in such numbers. So, there were really a lot of fights, and the police had to be called very quickly. (Miss Beck, pos. 77-78)

The "problem" with alcohol is viewed through the German attitude towards consuming alcohol, which is then transposed onto the refugee, who is assumed to have no ability to drink like a German (Miss Beck, pos. 66). In contrast, the consumption of illicit substances is portrayed as being imported from the country of origin. According to the bureaucrats, the difference between "the Germans" and "the refugees" leads to different health service preferences and outcomes; while Germans "want to make it low-threshold....We prefer to use self-help, which is at eye level. With the refugees, it's just the opposite.....And I only take one doctor seriously" (Miss Beck, pos. 51). The bureaucrat has made a mental division between the kind of services preferred by Germans, who appear to her more active and independent when seeking care for themselves, and the ones preferred by seemingly "passive" and "unaware" refugees. While Germans seem to be able to help themselves, refugees are presented as unable to do so. According to this, they find medical support helpful and use doctor-based services.

A further empirical aspect is that bureaucrats delineate belonging by defining "exploiters" of the health care system. They accuse refugees in general of overusing and abusing the health care system due to the lack of quality within the system of their countries of origin; Mister Weber assumes that the majority of refugees would say:

"I come from a country where I was persecuted, where I had no accommodation, where I felt very, very bad." And yes, that you feel that you are in a good position here that you and your family are taken care of here, that you can enjoy healthcare in particular too. (Mister Weber, pos. 20)

In the opinion of the bureaucrats, the introduction of an electronic health card would lead to refugees taking advantage of the system and moving around the country, as Miss Schumacher (pos. 81) describes: "This introduction would lead to the fact that people can also seek medical treatment nationwide and possibly also do a bit of doctor hopping." This estimation is underlined by the image of refugees as people who come from a country with a poor health care system which is apparently being 
entertained in certain political circles. The overall message appears to be that refugees are needy.

The discretion of the social welfare administration in approving health care services opens up opportunities for influencing the conditions under which refugees are (not) permitted access. While the formal hierarchy of refugees exists, of who is allowed to have access to the German health care system and who is not, there is also an unwritten hierarchy, where cases with scope for decision-making are passed into the hands of medical officers (Miss Schumacher, pos. 55; Mister Keller, pos. 91), other bureaucrats, like Miss Schumacher, set their own conditions: "If I know that he has applied for voluntary departure and will leave tomorrow or next week, I will no longer grant him psychotherapy....That's why we always check whether it's necessary or deferrable" (Miss Schumacher, pos. 87). With these aforementioned aspects, it becomes clear that Miss Schumacher is concerned with the economic side and not the medical. Only people who (supposedly and according to her conditions) remain in Germany in the long term deserve medical treatment. Additionally, there are normative aspects to consider: refugees must make an effort or prove themselves in order to gain access. Whereas a statutory insured person would apply for services to their health insurance provider, refugees who are insured by the Asylum Act have to apply to the social welfare office, which decides whether or not to approve a treatment. Mr. Keller as an employee within such an office who sets his standards by looking at "how serious is the will" and "does he really want to face the problem seriously?" Thus, whether one gets access and belongs (or not) is also about motivation and will. In the end, Mr. Keller takes a "spontaneous decision" (Mister Keller, pos. 99): For refugees, medical treatment turns out to be insecure and must be earned.

\subsubsection{Substance Using Refugees' Strategies}

The refugees are often searching for normality, and Hamsa explains what he counts as a normal life: "So I want to live a normal life, I want to find a job, I want to get married, make a family, have children" (Hamsa, pos. 135). Many refugees speak of boredom and living day-to-day, which leads them to substance use: "And that would be the big problem, this total living in the day. And no work. And above all, nothing to do. And boredom" (Fraug, pos. 92). A cycle can be seen here: The lack of normality leads to drug use, while escaping from substance use is the main goal of the majority, which seems to be achievable only through normality. However, the conditions for achieving belonging through the desired normality are difficult to reach: "And the worst thing is that you don't have work, that you are not busy. Therefore, all first what the brain thinks is again this returning to this dependence that one has" (Arash, pos. 32). Successfully finding a job depends on their residence status; not everyone has a work permit: "I would like to get my passport so that I am sure I can stay here so that I can achieve the goals I have set for myself so that I can offer something to society" (Reza, pos. 117). Reza describes his wishes for continuity and security, which he links with his economic usefulness.

Another coping strategy is to counter-respond with persistence by ally-seeking. Some of the contacts take part in a rehabilitation program only after becoming defiant towards individual bureaucrats or the health care system. For example, Reza first tried to find help by himself: "There were two or three places where I went, but unfortunately they did not accept me because they said, for example, that I was in the asylum procedure and I could not get that offer" (Reza, pos. 68). He kept trying to gain access by obtaining help from an "Iranian friend" (Reza, pos. 72). Since this path did not work out for him either, he turned to a social worker: "He said, 'no I will arrange an appointment for you.' If I do that then that will work, through him, I have been accepted here" (Reza, pos. 64). Only when Reza called in the home director did doors finally open up for him. This shows that knowledge and persistence alone are not enough and that allies from the dominant society are necessary. Also, other contacts had to fall back on their social workers as allies, but it did not always work out though; for example, Raghbir made energetic attempts to get help and asked his social worker, his doctor, going to the clinic a few times on his own, he even asked the researcher for help. However, it seemed as if no one could help him get the treatment he desperately needed (Raghbir, pos. 10-18).

A third coping strategy is to retract or resign. If no health care support is found, or even if a normal life is missing, consumption strategies are used as selfmedication: Sami, for example, drinks beer to deal with all the death and bloodshed he witnessed before his escape (Sami, pos. 1). While Raghbir consumes alcohol to treat physical pain after an accident left him with untreated injuries (Raghbir, pos. 68), Hamsa wants to banish the reoccurring thoughts and images that prevent him from falling asleep by smoking marijuana (Hamsa, pos. 159). Fraug wants to mediate his alcohol use through medication (Fraug, pos. 66). Finding it hard or even being denied access to the health care system leads in these cases to resignation and self-medication through drug use.

\section{Discussion}

According to our empirical findings, we can answer Carmel and Sojka's questions of who belongs, how much they belong, and under which conditions (Carmel \& Sojka, 2020) as follows. In all responding welfare institutions, bureaucrats focus on differences between German nationals and refugees and point to differential possibilities of (not) belonging. The bureaucrats' stereotypes of societal discourses about deservingness or cultural proximity play a major role. By attributing certain characteristics to the refugees such as passivity, independence, 
being unwilling, or being uneducated, they construct a difference between "us" and "them" analogous to what Anderson (2013) calls the "community of value." Thus, homogenized national Germans appear to be the normative standard by being self-responsible, active, and modern individuals that own access to social rights. As far as refugees are able to conform to such behavior, belonging seems feasible. However, those who use illicit substances, those who misuse the health care system, and Muslim refugee families with several children are perceived-in Anderson's words-as "failed citizens" with hardly any prospect of societal participation. Formal and informal access to social rights is at least questioned by the bureaucrats. While little administrative attention is being paid to (further) address female refugees and their needs (e.g., by offering them work-related or language training), it is important to the health care bureaucrats that misuse of the health care system needs to be discouraged by making exploitation and taking advantage of the system more expensive (for users) for its own protection-until then, controlling and reducing refugees' access to the German health care system is preferable to dealing with them. In cases where belonging seems possible from the bureaucrats' perspective, they set the conditions under which refugees potentially belong and thus stay in control of their access to certain social rights. Bureaucrats believe that substance use or living in seemingly patriarchal gender roles hinders refugees from belonging to German society, which sets up formal and informal barriers when claiming social rights. Finally, our empirical findings indicate the extent to which refugees can potentially belong, following the rationales of the bureaucrats. In case of substance-using, refugees' possibilities of belonging are interconnected with their addiction. While substance-use disqualifies refugees from being part of the community of value, partial belonging might be possible if substance-use were to stop. In the case of female refugees being accepted into the administration's activation efforts, they are mediated toward low-skilled jobs such as cleaning jobs. Partial belonging for them is possible if they accept labor market participation in predominantly low-level, specific ethnicgendered sectors.

Our research also illustrates the varying ways refugees handle access to social rights and how the way bureaucrats address them affects their emotional attachment and individual identification with German society. Those navigating the German health care system are in search of normality in order to belong to the community of value. While those who use substances are challenged by boredom throughout their everyday lives and seek to contact health services in order to escape from substance use, female refugees feel overburdened, misidentified, and demeaned by the labor market administration, its activation obligations, and bureaucrats' lecturing. None of our interview respondents mentioned a feeling of belonging. On the contrary, some refugees tended to exclude themselves from the system and their social surroundings, irrespective of the policy field. While (self-)exclusion from the labor market processing can come along with new possibilities for those female refugees who are socially anchored to heterosexual gender relations, resigning from the health care system might come at the cost of falling into substance use as a form of self-medication. Other refugees display resistance or persistence, but critical intervention from female refugees delivered hardly any effect. The same is true for substance-using refugees. To overcome certain limitations, allies from within the community of valuenot help from other migrants-appeared helpful.

In summing up, bureaucrats in the two policy fields adopt differential rationales of belonging. These rationales consist of a connection of political discourses and (in)formal access to social rights. Putting differential rationales into practice means institutionalizing processes of positioning and selecting between refugees and national Germans as well as among different groups of refugees, which are racialized, gendered, and classed. Refugees experience parallel processes of in- and exclusion in their everyday lives, which they do respond to somehow. However, the differentiation between strategies for belonging and the ascribed form of belonging is important, as Yuval-Davis already mentioned (Yuval-Davis, 2011, p. 25). This is also the case for the struggle and resistance of newly-arrived refugees in Germany.

\section{Conclusion}

There is an increasing interest in the complex, dynamic processes of stratification within migration studies that concepts of belonging attempt to portray (Anderson, 2013; Yuval-Davis, 2011). We labeled three different dimensions within these concepts: a person's emotional attachment, national entanglements of social rights, and societal discourses. While our empirical research is based on these concepts of belonging, we connect our findings of certain rationales of belonging with an active social citizenship as a recent context (not only) in the German welfare state. Although recent political discourses and institutional organization of social entitlements are moving towards activation, self-responsibility, and social investment, within the two policy fields (the labor market and health policy), they produce inclusion and exclusion for national citizens-and newly arrived refugees face additional challenges. Active social citizenship promotes belonging by being an active member of society and a good citizen, that is, one who participates in the labor force, has a family, and watches out for his or her own health. Refugees can hardly fulfill these formal and informal obligations and conditions, so employability for (Muslim) female refugees and health for substance-using refugees is achievable only on a basic level. The refugees themselves showed different ways of dealing with this, ranging from a search for normality, persistence, or retracting and resigning. Within the active German welfare state, refugees are made responsible for their own 
progress. The case of Germany typifies the self-reliance type with a minor role of the state that forces active social citizenship on people, rather than generously supporting it, at least in the labor market and health policies. Refugees-like other welfare dependants-are forced to be active by being confronted with obligations and minor funding, but at the same time, it is harder for them to comply with the normative standards of the "community of value" (Anderson, 2013). Other European welfare states such as Denmark differ in how they realize an active social citizenship; they refer to self-determination, alongside choice and autonomy, and the state has a major role and provides generous funding (Eggers et al., 2019 , p. 43). However, further research on the effectiveness of this approach is needed.

Additionally, our empirical findings reveal that bureaucrats in welfare institutions have a major impact on refugees' options for belonging. They set up boundaries concerning who belongs, how much they belong, and under which conditions. Besides the formal level of status positions, normative concepts of belonging and normative concepts of a good citizen become relevant and produce certain rationales of belonging. Our material also shows how bureaucrats shape or even counteract the paradigm of active social citizenship according to their ethnographic-cultural stereotypes and gendered assumptions around paid work and welfare. Thus, our material also points to the necessity of reflecting on processes of Othering and the meaning of institutional racism (Graevskaia et al., in press). Since our study is limited to two specific subgroups of refugees, it would be important to learn more about other migrant groups besides asylum contexts and to compare refugees with other groups of the wider German society, e.g., single mothers. This could reveal further commonalities and differences between subgroups at the edge of citizenship. Future research should further investigate the meaning of discourses within bureaucracies and administrations.

\section{Acknowledgments}

We thank the two anonymous reviewers and the editors for their appreciative and constructive comments on previous versions of the manuscript. Acknowledgments are also due to our funder, the Federal Ministry of Labour and Social Affairs, Germany.

\section{Conflict of Interests}

The authors declare no conflict of interest.

\section{References}

Amelina, A., Carmel, E., Runfors, A., \& Scheibelhofer, E. (Eds.). (2020). Boundaries of European social citizenship: EU citizens' transnational social security in regulations, discourses and experiences. Routledge.

Anderson, B. (2013). Us and them? The dangerous politics of immigration control (1st ed.). Oxford University Press. http://digitale-objekte.hbz-nrw.de/ storage2/2014/07/23/file_2/5685466.pdf

Ataç, I., \& Rosenberger, S. (2019). Social policies as a tool of migration control. Journal of Immigrant \& Refugee Studies, 17(1), 1-10. https://doi.org/ 10.1080/15562948.2018.1539802

Auth, D., Buchholz, E., \& Janczyk, S. (Eds.). (2010). Politik und Geschlecht-Selektive Emanzipation: Analysen zur Gleichstellungs- und Familienpolitik [Selective emancipation: Analyses of equal opportunity policy and family policy] (Vol. 21). Budrich. http://www.socialnet.de/rezensionen/isbn.php? isbn=978-3-86649-254-7

Betzelt, S. (2015). The myth of more social inclusion through activation reforms: The case of Germany (Working Paper No. 57). Berlin School of Economics and Law Institute for International Political Economy Berlin.

Bonoli, G., \& Natali, D. (2012). Multidimensional transformations in the early 21 st century welfare states. In G. Bonoli \& D. Natali (Eds.), The politics of the new welfare state (pp. 287-306). Oxford University Press.

Carmel, E., \& Sojka, B. (2020). Beyond welfare chauvinism and deservingness. Rationales of belonging as a conceptual framework for the politics and governance of migrants' rights. Journal of Social Policy, 50(3). https://doi.org/10.1017/S0047279420000379

Conrad, P., \& Barker, K. K. (2010). The social construction of illness: Key insights and policy implications. Journal of Health and Social Behavior, 51(Suppl. 1), S67-S79. https://doi.org/10.1177/0022146510383 495

Dietz, M., Osiander, C., \& Stobbe, H. (2018). Arbeitsmarktintegration von Geflüchteten aus Sicht der Vermittler: Online-Befragung in Arbeitsagenturen und Jobcentern [Labor market integration of refugees from the perspective of mediators: Online survey in employment agencies and job centers] (Brief Report No. 25). IAB.

Eggers, T., Grages, C., \& Pfau-Effinger, B. (2019). Selfresponsibility of the "active social citizen": Different types of the policy concept of "active social citizenship" in different types of welfare states. American Behavioral Scientist, 22(1), 43-64. https://journals. sagepub.com/doi/pdf/10.1177/0002764218816803

Ewert, B., \& Evers, A. (2014). An ambiguous concept: On the meanings of co-production for health care users and user organizations? VOLUNTAS: International Journal of Voluntary and Nonprofit Organizations, 25(2), 425-442. https://doi.org/10.1007/ s11266-012-9345-2

Flick, U. (2000). Qualitative inquiries into social representations of health. Journal of Health Psychology, 5(3), 315-324. https://doi.org/10.1177/1359105300005 00303

Ghorashi, H., \& van Tilburg, M. (2006). "When is my Dutch good enough?" Experiences of refugee women 
with Dutch labour organizations. Journal of International Migration and Integration, 7(1), 51-70. https://doi.org/10.1007/s12134-006-1002-4

Graevskaia, A., Menke, K., \& Rumpel, A. (in press). Institutioneller Rassismus in Behörden: Zur (Re-)Produktion alter und neuer rassistischer Wissensbestände in Polizei, Gesundheitsversorgung und Arbeitsverwaltung [Institutional racism in public authorities: On the (re-)production of old and new racist knowledge in the police, health care, and labor administration] (IAQ-Report). Institut Arbeit und Qualifikation der Universität Duisburg-Essen Duisburg.

Greer, I., \& Symon, G. (2014). Comparing workfare regimes: Similarities, differences, and exceptions (Working Paper No. WERU6). University of Greenwich Centre for Work and Employment Research (CREW); University of Greenwich Work \& Employment Research Unit (WERU).

Hagelund, A., \& Kavli, H. (2009). If work is out of sight: Activation and citizenship for new refugees. Journal of European Social Policy, 19(3), 259-270. https:// doi.org/10.1177/0958928709104741

Hollifield, J. (2000). Immigration and the politics of rights. The French case in comparative perspective. In $\mathrm{M}$. Bommes \& A. Geddes (Eds.), Immigration and welfare: Challenging the borders of the welfare state (pp. 109-133). Routledge.

Jaehrling, K., \& Knuth, M. (2010). Die Widerständigkeit von Geschlecht und Kultur im aktivierenden Sozialstaat [The resistance of gender and culture in activating welfare state]. In M. Knuth (Ed.), Arbeitsmarktintegration und Integrationspolitik. Zur notwendigen Verknüpfung zweier Politikfelder: Eine Untersuchung über SGB II-Leistungsbeziehende mit Migrationshintergrund [Labor market integration and integration policy. A necessary linkage of two policy fields: A study of SGB II benefit recipients with a migration background] (pp. 197-212). Nomos.

Koyama, J. (2015). Constructing gender: Refugee women working in the United States. Journal of Refugee Studies, 28(2), 258-275. https://doi.org/10.1093/jrs/ feu026
Kuckartz, U. (2016). Qualitative Inhaltsanalyse. Methoden, Praxis, Computerunterstützung [Qualitative text analysis: A guide to methods, practice, and using software]. Beltz.

Mezzadra, S., \& Neilson, B. (2012). Between inclusion and exclusion: On the topology of global space and border. Theory, Culture \& Society, 29(4/5), 58-75.

Morris, L. (2020). The topology of welfare-migrationasylum: Britain's outsider inside. Journal of Poverty and Social Justice, 28(2), 245-264.

Rothgang, H., Cacace, M., Grimmeisen, S., \& Wendt, C. (2005). The changing role of the state in healthcare systems. European Review, 13(Suppl. 1), 187-212. https://doi.org/10.1017/S1062798705000256

Rumpel, A., \& Tempes, J. (2019). Einbindung von Übersetzenden im Kontext der FluchtRollenverständnisse, Chancen und Herausforderungen [Engagement of translators in the context of flight role understandings, opportunities, and challenges]. In M. E. Kaufmann, L. Otto, S. Nimführ, \& D. Schütte (Eds.), Forschen und Arbeiten im Kontext von Flucht [Research and work in the context of flight] (pp. 193-213). Springer. https://doi.org/10.1007/978-3658-28380-3_9

Salikutluk, Z., \& Menke, K. (2021). Gendered integration? How recently arrived male and female refugees fare on the German labour market. Journal of Family Research. Advance online publication. https://doi. org/10.20377/jfr-474

Schwenken, H. (2021). Differential inclusion: The labour market integration of asylum-seekers and refugees in Germany. In B. Galgóczi (Ed.), Betwixt and between: Integrating refugees into the EU labor market (pp. 135-163). ETUI.

Strauss, A. L., \& Corbin, J. M. (1994). Grounded theory methodology: An overview. In N. K. Denzin \& Y. Lincoln (Eds.), The SAGE handbook of qualitative research (pp. 273-285). SAGE.

Yuval-Davis, N. (2011). Belonging and the politics of belonging. In J. McLaughlin, P. Phillimore, \& D. Richardson (Eds.), Contesting recognition. Culture, identity and citizenship (pp. 20-35). Palgrave Macmillan.

\section{About the Authors}

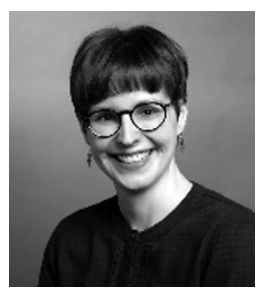

Katrin Menke holds a doctorate in sociology and works as a research assistant at the Institute for Work Skills, and Training at the University of Duisburg-Essen. As a member of the research group Migration and Social Policy, she is currently researching the labor market participation of refugee women from an intersectional perspective.

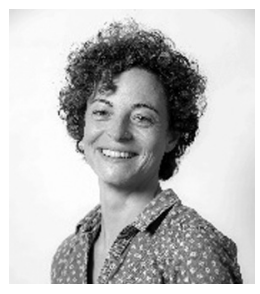

Andrea Rumpel studied educational science, sociology, and comparative religious studies at the University of Tübingen until 2013 and started dealing with the topics of asylum and (forced) migration. Since October 2017, she has been working on her doctoral thesis within the Migration and Social Policy research group at the Institute for Work, Skills and Training at the University of Duisburg-Essen on the topic "Refugees and Local Health Policy: A Qualitative Study Exemplified by Substance Use." 